purpose of the volume is to offer a various and comprehensive study of the relation between these two disciplines in different literatures in English. Ranging from Salman Rushdie to Angela Carter and from Victorian to postmodern fiction, the essays collected intend to provide analyses of the different ways in which the fictional integration of historical elements affects (and is affected by) narrativization and the structure of the novel (both as individual work and as genre). The essays explore issues related to genre criticism and authorial intention (1) showing how the construction of concepts such as subjectivity or social representation, among others, are historically determined and (2) unveiling how these historical constructions are subject to the kind of rhetorical deconstructive (postmodern) readings that disclose their institutional interests.

To sum up, "historical understanding" appears, in the context of contemporary fiction, as a notion hardly distinguishable from that of "literary study," given the reflexive interests of so many postmodern novels. The fictional examination of history through its own narrative devices opens the way for a critique of literature as pure textuality. However, in this collection as well as in others, the question remains to ellucidate what kind of intellectual and ethical agency these "new historicist" novels can ultimately articulate. Perhaps a study of the parallel interests of history and fiction will someday give us a hint.

Ricardo Miguel Alfonso

\title{
José Manuel González Fernández de Sevilla. El teatro de William Shakespeare hoy. Montesinos, 1993.
}

This short and eloquent book contains a well-illustrated life of Shakespeare from his birthplace to his tomb, a chronology of his life, works and contemporaries, and an excellent bibliography. But the most significant word in the title is the last. What does Shakespeare mean to us today? Jan Kott, to whom Dr. González refers, knew very well that Shakespeare was the contemporary of Queen Elizabeth and James I, of Sidney and Donne, of Bacon and Hooker, of the Spanish Armada and the Gunpowder Plot. By saying that Shakespeare was our contemporary, he was merely stressing the fact that each new generation, each audience indeed, believes that the plays speak directly to them. What was true of Polish audiences after years of Soviet domination is equally true of British ones today.

An actor, Leslie Sands, described in his autobiography of his experience of playing the title-role in Coriolanus during the Second World War, and how he found that text-book interpretations of the play were turned upside down. The hero and his aristocratic supporters seemed to be fascists, only the warhating wife of the hero aroused the sympathy of the audience. The citizens, usually regarded as irrational and cowardly, spoke good sense in educated accents. Even the Tribunes, regarded by Conservatives as detestable villains, emerged as serious trade union leaders defending the interests of their class against the threat of dictatorship. Dr. González makes a similar point: "La rebelión parece ser más que justificada ante unas circumstancias de supervivencia insostenibles.” 
It is important to note that Shakespeare always provides the evidence for the defence as well as for the prosecution. The ambivalence of his art enables directors to pick and choose interpretations either to satisfy the expectations of the age or to confound them. Olivier's film of Henry $V$ in 1944 was inevitably patriotic, but like Branagh's more realistic one in 1990, it was based securely on the text. Sometimes there are surprises. Kozintsev's great film of King Lear coming from an officially atheist regime was essentially Christian in spirit, whereas Brook's film of the same year belonged clearly to the Theatre of the Absurd.

Dr. González's radical position involves the repudiation of a merely literary Shakespeare, embalmed in Quartos and Folios, demanding worship and orthodoxy. Instead he wants a fluid Shakespeare based on performances. I would agree that this is better suited to an actor and playwright who belonged to the most popular company of his time, than the god-like figure almost divorced from the practical job to which he gave his life. My only doubt is caused by the fact that although there are dozens of legitimate interpretations of each of the plays, there are scores of illegitimate ones. I am reminded of a production at Stratford at which I sat next to a theologian of my acquaintance. We both thought the production was unforgiveably silly, and I asked my friend if he would give me absolution if I were to shoot the director. He replied: "Plenary absolution."

Dr. González discusses many of the plays from his radical standpoint. There is, for example, a fine analysis of the abdication scene in Richard II and of Bolingbroke's sense of guilt. Perhaps the Shrew's submission is best played ironically, as it was by Edith Evans and other great actresses. It has always been recognized that the heroines of the comedies are greatly superior to the young men they eventually marry, as the young women in Spanish comedies of the Golden Age far outshine the men. Shakespeare, we may suppose, deplored the macho characteristics of his society, although, I suspect, Dr. González sometimes overstresses the feminist outlook. He laments that Isabella in Measure for Measure is forced to marry the Duke; but I have seen one production in which she declines his hand. Yet, if she admired and loved him as her spiritual adviser, it would surely be possible for the pious heroine to transfer her affections to Vincentio when he turns out to be the ruler. They are well matched.

Kenneth Muir

\section{Rose Petterson. Nadine Gordimer's One Story of a State Apart. Stockholm: Uppsala University, 1995.}

In her detailed study of Gordimer's work, Nadine Gordimer's One Story of a State Apart, Rose Petterson seeks to establish two main themes which she can interrelate: the political system of apartheid in South Africa and the feminist perspective. With these premises, the five chapters of her book cover different variations on these themes, illustrated with an analysis of her novels which very wisely does not follow a chronological order.

Gordimer's openly political involvement with apartheid in her creative writing is noticeable from her earliest work. Most of her fellow-members in the privileged white 